\title{
PEMROSESAN INFORMASI PANDEMI COVID-19 DARI FACEBOOK
} PROCESSING INFORMATION ABOUT COVID-19 FROM FACEBOOK

\author{
B. Lenny Setyowati \\ Universitas Katolik Soegijapranata \\ email: setyowati@unika.ac.id
}

\begin{abstract}
This study aims to understand individual experiences in processing information about Covid-19 from Facebook. This type of research is qualitative with a phenomenological approach. The result of this research is that information processing in an individual's cognitive system begins when the individual is exposed to information related to Covid-19. Information about Covid-19 encourages individual involuntary attention, because at first the individual is faced with an unaware situation, which assumes that information about Covid-19 is not a daily informational goal. In its development, information about Covid-19 has begun to be placed as information that needs to be accessed. Some information can attract individual attention, thus encouraging their motivation to follow the development of that information. In addition, the presence of information about Covid-19 also encourages curiosity and causes cognitive dissonance in individuals. Information about Covid-19 that is filtered by individuals in the cognitive system, encourages the formation of individual cognitive structures and attitudes. There are three interpretations of hoaxes about Covid-19 that are understood by individuals, which are predominantly obtained through Facebook. However, hoaxes about Covid-19 are also transmitted via WhatsApp, Twitter, word of mouth (WOM), and even online news portals.
\end{abstract}

Keywords: Processing, Information, Hoax, Covid-19

\begin{abstract}
Abstrak
Penelitian ini bertujuan untuk memahami pengalaman individu dalam memproses informasi tentang Covid-19 dari Facebook. Tipe penelitian ini adalah kualitatif dengan pendekatan fenomenologi. Hasil dari penelitian ini yaitu pemrosesan informasi dalam sistem kognitif individu dimulai sejak individu terterpa informasi yang berkaitan dengan Covid-19. Informasi tentang Covid-19, mendorong terjadinya involuntary attention individu, karena pada awalnya individu dihadapkan pada situasi unaware, yang menganggap bahwa informasi mengenai Covid-19 bukan sebagai informational goal sehari-hari. Pada perkembangannya, informasi tentang Covid-19 mulai ditempatkan sebagai informasi yang perlu diakses. Sejumlah informasi dapat menarik perhatian individu, sehingga mendorong motivasi mereka untuk mengikuti perkembangan informasi tersebut. Selain itu, kehadiran informasi-informasi tentang Covid-19 juga mendorong rasa penasaran dan menyebabkan cognitive dissonance pada individu. Informasi-informasi tentang Covid-19 yang disaring individu dalam sistem kognitif, mendorong pembentukan struktur kognitif dan sikap individu. Terdapat tiga pemaknaan mengenai hoaks tentang Covid-19 yang dipahami individu, yang secara dominan diperoleh melalui Facebook. Namun demikian, hoaks tentang Covid-19 juga ditransmisikan melalui (grup) WhatsApp, Twitter, word of mouth (WOM), bahkan portal berita online.
\end{abstract}

Kata Kunci: Pemrosesan, Informasi, Hoaks, Covid-19 


\section{PENDAHULUAN}

Informasi yang berkaitan dengan pandemi Covid-19 cenderung dapat memunculkan fenomena aktivitas pemrosesan informasi di dalam sistem kognitif individu yang mengaksesnya dari media sosial. Adanya kasus hoaks yang membanjiri masa pandemi ini, berpotensi memunculkan ketidaksesuaian kognitif dan perubahan afeksi diantara khalayak media sosial yang berbasis internet.

Ketidaksesuaian kognitif atau cognitive dissonance merupakan keadaan emosional yang tidak menyenangkan yang dirasakan ketika terjadi ketidakkonsistenan logis di antara unsurunsur kognitif (Mowen \& Minor, 2002). Menurut hasil penelitian yang dilakukan oleh Nikolaus Ageng Prathama (2019) mengenai "Aktivitas Pemrosesan Informasi SARA dari Media Sosial", terutama dalam konteks interaksi pengguna internet dengan suatu informasi yang diaksesnya adalah ketidaktahuan pengguna bahwa informasi yang sedang diaksesnya merupakan hoaks atau berita faktual (Prathama, 2019). Oleh karena itu, keberadaan hoaks yang berkaitan dengan Covid-19, juga cenderung menjadi tantangan digital bagi para pengguna internet.

Salah satu informasi yang diindikasikan sebagai hoaks dan beredar luas lewat media sosial (WhatsApp) yaitu mengenai bawang putih yang dapat digunakan sebagai sarana pengobatan Covid-19. Dalam kontennya dijelaskan bahwa mengkonsumsi bawang putih dapat mencegah terinfeksi Covid-19 (Prathama, 2019). Namun demikian, menurut penilaian dari Direktur Jenderal Pencegahan dan Pengendalian Penyakit (P2P) Kementerian Kesehatan, Dokter Anung Sugihantono, informasi mengenai manfaat bawang putih untuk mencegah virus Covid-19 ini merupakan hoaks. la menuturkan: "Yang harus diwaspadai saat ini adalah kemudian ada orang-orang tertentu, kelompok tertentu yang mengintrodusir bahan-bahan tertentu. Kemarin yang sudah muncul bawang putih, semua makan bawang putih padahal bawang putihnya impor nah nanti kita malah kebanyakan impor"(detik.com, 31 Januari 2020).

Pada situasi yang berbeda, seorang dokter ahli imunologi, Iris Rengganis juga menyatakan bahwa penelitian yang dilakukan terhadap manfaat bawang putih untuk mencegah Covid-19 belum teruji (cnnindonesia.com, 29 Januari 2020).

Permasalahan lain pun muncul mengenai adanya informasi pasien yang terinfeksi Covid19 di salah satu rumah sakit di Semarang pada Februari 2020, sehingga memicu kepanikan publik. Setelah informasi ini beredar, pengelola rumah sakit memberikan klarifikasi bahwa informasi yang berupa video tersebut merupakan hoaks dan hasil suntingan orang tidak dikenal (detik.com, 2 Februari 2020).

Berbagai respons bermunculan oleh karena banyaknya informasi yang beredar secara masif, terutama melalui media sosial. Salah satu respon yang muncul dan dicermati dalam penelitian ini adalah respon afektif (perasaan), yaitu gambaran perasaan dan emosi yang dihasilkan oleh sebuah stimulus (Engel, Blackwell, \& Miniard, 1995). Bentuk respon afektif pengguna internet terhadap hoaks mengenai Covid-19 misalnya kecemasan, marah, dan panik.

Menurut Menteri Komunikasi dan Informasi, Johnny G. Plate, selama masa pandemi Covid-19 terdapat 554 hoaks yang disebarkan melalui Facebook, Twitter, Instagram, dan Youtube. Terdapat 89 orang tersangka dan 14 orang yang ditahan karena menyebarkan hoaks terkait dengan Covid-19 (detik.com, 18 April 2020). Di tempat lain, hasil penelitian yang dilakukan oleh Masyarakat Telematika Indonesia tentang "Wabah Hoaks Nasional 2019" terungkap bahwa saluran penyebaran hoaks yang terbanyak adalah media sosial, yaitu 87,50 persen, aplikasi chatting 67 persen, dan website 28,20 persen. Sementara berdasarkan data 
yang dikeluarkan oleh Asosiasi Penyelenggara Jasa Internet Indonesia (APJII), jumlah pengguna internet di Indonesia mencapai hampir 55 persen atau 132 juta penduduk. Sebanyak 54 persen merupakan pengguna Facebook dan 5,54 persen adalah pengguna Twitter (kompas.com, 18 April 2017). Oleh karena itu, setiap pengguna internet dan media sosial, terutama Facebook, berpotensi terpapar hoaks.

Dari pembahasan tersebut, tampak bahwa masalah yang muncul di antara para pengguna internet pada khususnya Facebook yaitu kurangnya kemampuan mereka dalam membedakan hoaks dan fakta, ketidaksesuaian kognitif yang dihasilkan dari terpaan hoaks, perubahan emosional, serta ancaman hukuman pidana yang dapat dikenakan kepada para penyebar hoaks. Oleh karena itu, tujuan studi ini adalah memahami pengalaman individu dalam memproses informasi tentang Covid-19 dari Facebook.

Penelitian sebelumnya yang disusun oleh Abner, Khaidir, Mohammad Ridho Abdillah, Rizky Bimantoro, dan Weiby Reinaldy (2017) berjudul "Penyalahgunaan Informasi Hoaks di Media Sosial" mengungkap adanya potensi penyebaran hoaks yang berkaitan dengan peningkatan jumlah pengguna internet di Indonesia.

Di sisi lain, Fahmi Anwar (2017), melalui riset yang berjudul "Perubahan dan Permasalahan Media Sosial", menemukan bahwa penggunaan media sosial telah mengubah psikologi khalayak serta adanya fenomena yang disebut hoaks, cyber-hate, dan cyber-bullying yang memunculkan masalah baru.

Untuk melengkapi penelitian-penelitian sebelumnya, studi ini difokuskan pada pemrosesan informasi mengenai Covid-19 dari Facebook yang dilakukan oleh pengguna internet, dengan harapan dapat mengungkap fenomena banjirnya hoaks tentang Covid-19.

Studi ini menggunakan genre interpretif, tradisi sibernetika (cybernetics of knowing), dan fenomenologi sebagai dasar berpikir teoritik. Untuk melihat perilaku individu dalam berinteraksi dengan informasi, digunakan Information Seeking Theory. Namun, untuk mengkaji bagaimana individu mengevaluasi berbagai informasi yang masuk ke dalam sistem kognitifnya digunakan Elaboration Likelihood Theory (ELT) yang dikembangkan oleh Richard Petty dan John Cacioppo.

Kapan dan bagaimana individu akan terbujuk dan tidak akan terbujuk oleh pesan diprediksi dalam teori persuasi ELT (Littlejohn \& Foss, 2008). Elaborasi mengacu pada banyaknya integrasi diantara informasi baru dan pengetahuan yang sudah disimpan di dalam ingatan atau memori (Engel, Blackwell, \& Miniard, 1995).

\section{METODOLOGI PENELITIAN}

Penelitian ini merupakan tipe penelitian kualitatif yang menggunakan pendekatan fenomenologi, sehingga indepth interview dikedepankan untuk memperoleh data primer dari pengalaman lima orang subjek penelitian yang memiliki kualifikasi khusus yaitu mencermati berbagai fenomena hoaks tentang Covid-19 di Facebook dan berdomisili di Kota Semarang sebagai representasi wilayah yang termasuk zona merah penyebaran Covid-19 serta ada di posisi pertama sebagai daerah merah di Provinsi Jawa Tengah (cnnindonesia.com, 2 Juli 2020).

Pemilihan subjek penelitian dilakukan dengan beberapa kualifikasi. Terlebih dahulu dilakukan observasi non partisipan dan trial wawancara. Langkah berikutnya, setelah menemukan subjek dan melakukan indepth interview, dilakukan penyusunan thematic 
portrayal, yang bertujuan untuk mengungkap pengalaman setiap subjek yang bervariasi kedalam tema-tema pokok penelitian, sehingga makna inti dapat ditemukan.

Deskripsi tekstural dari pengalaman seluruh subjek dan deskripsi struktural disusun oleh peneliti sebagai langkah selanjutnya dari tahapan penelitian. Horison-horison pengalaman personal subjek penelitian dikonstruksikan menjadi deskripsi tekstural.

Sementara itu, gambaran pengalaman unik dan segala hal yang berkaitan dengan pengalaman tersebut merupakan deskripsi struktural. Tindakan berpikir sadar, penilaian, imajinasi, dan mengumpulkan segala hal yang berhubungan dengan pengalaman diperlukan dalam deskripsi struktural. Tindakan-tindakan tersebut bertujuan agar inti makna struktural pengalaman dapat dicapai, sehingga "the how" dapat digambarkan dan "the what" dari suatu pengalaman dapat dijelaskan (Moustakas, 1994).

Dalam studi fenomenologi, setelah melakukan langkah-langkah tersebut di atas, maka penggambaran sintesis makna dan struktural menjadi langkah selanjutnya. Tujuannya adalah menggabungkan deskripsi tekstural dan struktural secara intuitif kedalam sebuah kesatuan pernyataan mengenai esensi pengalaman dari suatu fenomena secara keseluruhan (Moustakas, 1994).

\section{HASIL DAN PEMBAHASAN}

\section{Aktivitas Mengakses Informasi dari Media Sosial}

Dalam kehidupan sehari-hari, para individu mengakses berbagai informasi seperti berita teraktual (politik, ekonomi, sosial, olahraga, keuangan, budaya, seni), hiburan (gosip artis dan berita otomotif), informasi yang berkaitan dengan bisnis, kesehatan, perkembangan teknologi, relasi sosial, gaya hidup, resep makanan, maupun informasi yang berkaitan dengan bidang akademik atau ilmiah. Secara dominan, informasi-informasi tersebut diperoleh melalui media internet.

Berbagai situs yang diakses untuk memperoleh informasi antara lain e-mail, mesin pencari, portal berita online, jurnal penelitian, situs resmi pemerintah pusat dan daerah (covid19.go.id dan semarangkota.go.id), serta Facebook, Twitter, Instagram, Youtube, aplikasi Line, dan WhatsApp. Hampir setiap hari, mereka terhubung dengan jaringan internet aktif melalui handphone atau komputer (laptop). Namun demikian, mereka juga masih mengakses informasi tambahan melalui saluran televisi, media luar ruang (billboard atau poster), berbagai media cetak, bahkan word of mouth (WOM) melalui kegiatan face-to-face interaction.

Fenomena keseharian para individu tersebut, memperlihatkan bahwa dalam menjalani aktivitas sehari-hari, mereka tidak bisa menghindar dari aktivitas tukar-menukar informasi. Semua informasi yang diperoleh, baik pengetahuan maupun pengalaman yang datang dari luar maupun dari dalam diri diolah dalam bagian jiwa manusia yang disebut kognisi. Hasil pengolahan tersebut menjadi simpulan-simpulan yang selanjutnya menghasilkan perilaku (Sarwono, 1999). Keaktifan mereka mencari dan mengakses informasi, mendorong terjadinya pemrosesan informasi dalam sistem kognisinya secara berkelanjutan. Hal ini sebagai akibat dari adanya aktivitas information seeking. Para ahli yang mengembangkan pemikiran Information Seeking Theory menjelaskan bahwa para pengguna informasi dapat menggunakan media komunikasi yang bermacam-macam bentuknya, yang dimaksudkan untuk mencari dan menemukan informasi yang diinginkannya (Yusup \& Subekti, 2010). Individu secara aktif 
melakukan selective exposure terhadap beragam informasi yang mereka akses setiap hari, yang berkaitan dengan aktivitas rutin ataupun sebagai informasi tambahan saja.

Dibandingkan dengan jenis media lainnya, media internet lebih dipilih sebagai media gratifications yang lebih diutamakan daripada jenis media lainnya. Penentuan jenis media, pada konteks ini hanya sebagai akibat dari seleksi jenis informasi. Seleksi "prioritas" cenderung dilakukan para individu pada jenis pesan atau informasi yang berkaitan secara langsung dengan aktivitas utama mereka sehari-hari, sehingga media internet dipahami sebagai "infrastruktur penting" untuk menopang kelancaran aktivitas utama.

Selain itu, mereka juga terhubung secara aktif dengan situs media sosial seperti Instagram, Facebook, Twitter, Youtube, aplikasi Line, WhatsApp, dan lain-lain untuk memperoleh informasi teraktual. Nasrullah menjelaskan bahwa keunikan media sosial yaitu membentuk masyarakat berjejaring (network society), sehingga distribusi informasi dapat berlangsung terus-menerus (Nasrulah, 2015).

Faktor penting yang berkaitan secara langsung dalam aktivitas individu mengakses informasi dari internet adalah tersedianya perangkat teknologi seperti handphone dan komputer (laptop), yang lebih bersifat private (safety) serta dapat menghubungkan individu dengan koneksi atau jaringan aktif internet. Oleh karena itu, mobilitas mereka dalam beraktivitas secara personal maupun sosial, cenderung tidak mengalami hambatan yang berarti.

Wilbur Schramm melakukan sebuah studi mengenai perilaku khalayak dalam memilih media tertentu. Dalam hasil temuannya, dijelaskan bahwa individu cenderung menerapkan prinsip kemudahan dan prinsip harap imbalan dalam menentukan jenis media yang dipilihnya (Rivers, Jensen, \& Peterson, 2003). Jenis media seperti televisi, media cetak (koran dan majalah), atau media luar ruang (billboard dan poster) juga tersedia dan relatif mudah diperoleh oleh para individu. Namun demikian, sekarang ini penggunaannya tidak terlalu menonjol dalam keseharian mereka. Jika dibandingkan dengan internet, terutama di kota-kota besar, karena dapat diakses dengan lebih mudah.

\section{Pemrosesan Informasi Covid-19 oleh Individu}

Berbagai informasi tentang Covid-19 yang berasal dari sejumlah saluran informasi dan komunikasi diproses ke dalam sistem kognisi individu. Upaya pemrosesan tersebut dapat diperhatikan dari gambaran pengalaman seluruh subjek penelitian yaitu: (1) Proses Kognitif Informasi Covid-19; serta (2) Struktur Kognitif Fenomena Hoaks Covid-19.

\section{Proses Kognitif Informasi Covid-19}

Menurut pengamatan individu, informasi tentang Covid-19 relatif mudah ditemukan melalui televisi, koran, portal berita online, dan situs resmi pemerintah. Oleh karena itu, dalam beraktivitas sehari-hari individu memiliki peluang untuk menerima terpaan informasi Covid-19 sewaktu-waktu. Terpaan merupakan suatu tindakan menerima komunikasi, baik secara pasif atau aktif dari sumbernya (Berelson \& Steiner, 1964). Namun demikian, informasi Covid-19 juga ditransmisikan melalui Facebook, Twitter, Instagram, dan aplikasi WhatsApp (grup).

Informasi mengenai Covid-19 diawali dari kemunculan Covid-19 di Wuhan Tiongkok. Perkembangan kasus secara global, kasus pertama di Indonesia, kasus pertama di Semarang, penolakan pasien oleh warga, pengobatan penyakit, perkembangan kasus di Indonesia, kemunculan klaster baru, jumlah orang yang terinfeksi dan meninggal karena virus Covid-19, perkembangan penemuan vaksin, 
kontroversi tentang konspirasi Covid-19, kebijakan sosial masa pandemi, pembelian vaksin dari Tiongkok, hingga prediksi berakhirnya pandemi Covid-19.

Kemunculan informasi-informasi tersebut, cenderung mendorong involuntary attention mereka secara individual. Dalam perspektif komunikasi pemasaran, involuntary attention (perhatian yang tidak disengaja) terjadi ketika para konsumen (individu) diekspos pada sesuatu yang mengejutkan, baru, mengancam, atau tidak terduga dan mereka menanggapinya secara otonomis dengan mengarahkan serta mengalokasikan perhatian pada rangsangan yang ada (Mowen \& Minor, 2002).

Pada awalnya, para individu dihadapkan pada situasi unaware, karena informasiinformasi yang muncul tersebut tidak menjadi bagian dari informasi yang dipilih untuk aktivitas sehari-hari (informational goal) mereka. Kemunculan informasi-informasi tentang Covid-19 merupakan dampak lain, yang merupakan secondary effect dalam aktivitas mereka memilih serta mengakses informasi sehari-hari. Namun demikian, sejak terjadi kasus pertama di Indonesia dan cenderung bertambahnya sejumlah kasus orang yang terinfeksi positif Covid-19 di sejumlah daerah yang diberitakan oleh media serta berbagai saluran informasi khalayak, para individu cenderung menempatkan informasi tentang Covid-19 sebagai bagian dari informasi yang perlu untuk diakses. Oleh karena itu, mereka melakukan information grouping untuk informasi yang bersifat aktualdomestik, informasi tambahan, dan informasi yang berkaitan dengan Covid-19.

Para ahli psikolog kognitif menyatakan bahwa setiap hari individu terekspos dengan berbagai informasi dalam jumlah yang sangat besar. Namun demikian, informasi-informasi tersebut disaring, sehingga hanya sebagian kecil informasi yang dapat mencapai pikiran sadar dan menarik perhatian individu untuk diproses serta disimpan dalam memori jangka panjang (Baran \& Davis, 2010). Proses ini terjadi di dalam sistem kognitif individu.

Sebagian dari informasi Covid-19 yang diperoleh dan diingat oleh para informan, dapat menarik perhatian (attention) dan memotivasi (motivation) mereka untuk mengikuti perkembangannya. Pada tahap ini, terjadi pemrosesan sejumlah informasi yang berkaitan dengan Covid-19 dalam sistem kognitif individu.

Mowen dan Minor menjelaskan bahwa pemrosesan informasi merupakan proses di mana para konsumen (individu) diarahkan menuju informasi, diajak untuk mencari informasi, memahami informasi, menempatkan informasi di dalam memori mereka, dan membukanya kembali untuk dipergunakan kemudian (Mowen \& Minor, 2002: 78). Pada saat individu terpapar informasi Covid-19 yang menarik perhatiannya (attention), mereka termotivasi (motivation) untuk mengikuti perkembangan informasi tersebut melalui berbagai saluran informasi dan komunikasinya. Motivasi yang diartikan sebagai kecenderungan (suatu sifat yang merupakan pokok pertentangan) dalam diri seseorang yang membangkitkan topangan dan tindakan (Setiadi, 2003), dalam konteks kasus Covid-19 ini, berwujud keinginan individu untuk mengikuti perkembangan dari suatu informasi Covid-19 yang diperolehnya.

Richard Petty dan John Cacioppo menjelaskan gagasannya melalui Elaboration Likelihood Theory (ELT) bahwa individu (komunikator) akan berusaha memproses pesanpesan persuasif dengan caranya (Littlejohn, Foss, \& Oetzel, 2017). Informasi yang diikuti perkembangannya oleh individu antara lain kebijakan bantuan sosial masa pandemi, 
perkembangan penyebaran virus, penolakan pasien (seorang perawat Rumah Sakit Kariadi) yang terinfeksi Covid-19 oleh warga, dan dampak pandemi bagi sektor lain. Keempat informasi ini mendorong rasa penasaran dan menyebabkan cognitive dissonance pada individu.

\section{Struktur Kognitif Fenomena Hoaks Covid-19}

Dari aktivitas berinteraksi dengan berbagai informasi mengenai Covid-19 yang tidak disengaja maupun yang disengaja, di dalam sistem kognitif individu terbangun sebuah struktur pengetahuan mengenai fenomena Covid-19. Dalam catatan Sarlito Wirawan Sarwono dijelaskan bahwa struktur pengetahuan (kognitif) merupakan serangkaian sifat (attributes) yang terorganisasi dan digunakan oleh individu untuk mengidentifikasi serta mendiskriminasi suatu objek atau peristiwa tertentu (S. W. Sarwono, 2013). Struktur kognitif berasal dari pemahaman individual para individu secara menyeluruh mengenai sejumlah informasi tentang Covid-19 yang telah diprosesnya. Pemahaman yang dimaksud mengacu pada bagaimana konsumen (individu) mengorganisasikan dan menginterpretasikan informasi (Mowen \& Minor, 2002).

Proses pembentukan pemahaman individu terjadi dalam aktivitas komunikasi mereka sehari-hari melalui perubahan skema kognitif (cognitive) dan sikap atau suasana emosional (affective) individu. Skema kognitif diartikan sebagai naskah dalam pikiran individu mengenai alur suatu peristiwa (Ardianto, Komala, \& Karlinah, 2009). Skema ini cenderung berubah ketika individu memberikan perhatian (attention) pada sejumlah informasi baru yang mendekati mereka, yang kemudian diproses, sehingga terjadi penambahan input dalam sistem kognisi individualnya, dan terungkap melalui berbagai penilaian, pendapat, ataupun ungkapan, dan ekspresi emosional serta perilaku komunikasi tertentu mereka ketika berinteraksi dengan informasi Covid-19 yang dianggap atau telah terkonfirmasi sebagai hoaks. Sementara itu, sikap diartikan sebagai perasaan umum, baik negatif maupun positif, yang berkelanjutan terhadap-atau penilaian evaluatif terhadap-seseorang, sebuah objek, atau suatu masalah (Shimp, 2000). Sikap juga mencakup ungkapan atau ekspresi emosional individu seperti kekecewaan, kemarahan, cenderung tenang, dan perilaku-perilaku komunikasi tertentu ketika mereka berinteraksi dengan hoaks-hoaks tentang Covid-19.

Keberadaan hoaks tentang Covid-19 ditransmisikan secara dominan melalui unggahan di Facebook. Namun demikian, sejumlah saluran lainnya yaitu (grup) WhatsApp, Twitter, bahkan word of mouth (WOM) dalam aktivitas face-to-face interactions, juga menjadi medium hoaks. Ditambah lagi bila seorang individu menyoroti sebuah portal berita online yang juga terlibat dalam penyebaran hoaks tentang Covid19. Hoaks, dalam penjelasan Conner, dapat diciptakan dengan suatu pernyataan yang benar, namun dengan kata-kata yang memiliki konteks berbeda (Conner, 2011). Namun demikian, dalam studi ini, terdapat tiga pemaknaan mengenai hoaks tentang Covid-19 yang dipahami oleh para individu. Pertama, hoaks tentang Covid-19 merupakan berita yang tidak berdasarkan fakta. Terdapat upaya untuk menggeser fakta yang akurat ke arah yang salah atau menampilkan realitas yang tidak utuh. Kedua, hoaks tentang Covid19 adalah berita aneh dan dapat memprovokasi atau menyesatkan banyak orang. Ketiga, hoaks tentang Covid-19 merupakan informasi yang tidak masuk akal. 
Sejumlah informasi yang dinilai atau telah terkonfirmasi sebagai berita hoaks mengenai Covid-19 antara lain denda sebesar 100.000 hingga 150.000 rupiah bagi warga Jawa Tengah yang tidak mengenakan masker, adanya seorang warga yang meninggal karena terinfeksi virus Covid-19, manfaat bawang putih sebagai obat penderita Covid-19, virus Covid-19 dapat menular melalui handphone, pembentukan daerah yang disebut zona hitam, thermo gun berbahaya bagi otak manusia, dan lain sebagainya.

Terkait dengan bentuk fisik hoaks tentang Covid-19 yang diperoleh individu, berwujud artikel berita, artikel dan gambar, gambar, serta video. Bentuk fisik berita hoaks ini berkaitan dengan jenis saluran informasi yang digunakan untuk mentransmisikan informasi-informasi tersebut.

Hikmahnya, penyebaran hoaks mengenai Covid-19 yang cenderung semakin meresahkan dalam masa pandemi ini, mendorong individu untuk lebih berhati-hati dalam merespon setiap informasi.

Seorang subjek penelitian mengklasifikasi penyebar hoaks ke dalam dua kategori, yaitu orang yang memahami informasi yang disebarkannya sebagai hoaks, namun tetap menyebarkan kepada orang lain serta orang yang tidak memahami bahwa informasi yang diperoleh dan disebarkannya merupakan hoaks.

Terkait dengan peran pemerintah dalam menghadapi hoaks tentang Covid-19 di masa pandemi, terdapat dua pendapat yang berbeda di antara para subjek. Pertama, dua orang subjek menilai bahwa pemerintah tidak tegas dalam menindak para pelaku (produsen dan penyebar) hoaks. Penilaian ini didasarkan pada masih adanya hoaks yang relatif mudah ditemukan melalui (grup) WhatsApp atau Twitter. Selain itu, kritik lain juga muncul yang menganggap bahwa upaya pemerintah belum maksimal dalam menangani fenomena Covid-19. Kedua, tiga orang subjek menilai bahwa pemerintah telah bertindak cepat dalam menangani kasus hoaks tentang Covid-19. Penilaian ini muncul dalam konteks Gubernur Jawa Tengah, Ganjar Pranowo, yang sigap mengklarifikasi informasi denda bagi warga Jawa Tengah yang tidak bermasker sebagai hoaks. Selain itu, respon pemerintah dalam menanggapi hoaks thermo gun yang dapat merusak otak dan melakukan pemblokiran terhadap situs penyebar hoaks juga diapresiasi oleh para individu.

\section{KESIMPULAN}

Hasil dari penelitian ini yaitu pemrosesan informasi dalam sistem kognitif individu dimulai sejak individu terterpa informasi yang berkaitan dengan Covid-19. Informasi tentang Covid-19, mendorong terjadinya involuntary attention individu, karena pada awalnya individu dihadapkan pada situasi unaware, yang menganggap bahwa informasi mengenai Covid-19 bukan sebagai informational goal sehari-hari. Pada perkembangannya, informasi tentang Covid-19 mulai ditempatkan sebagai informasi yang perlu diakses. Sejumlah informasi dapat menarik perhatian individu, sehingga mendorong motivasi mereka untuk mengikuti perkembangan informasi tersebut. Selain itu, kehadiran informasi-informasi tentang Covid-19 juga mendorong rasa penasaran dan menyebabkan cognitive dissonance pada individu. 
Informasi-informasi tentang Covid-19 yang disaring individu dalam sistem kognitif, mendorong pembentukan struktur kognitif dan sikap individu. Terdapat tiga pemaknaan mengenai hoaks tentang Covid-19 yang dipahami individu, yang secara dominan diperoleh melalui Facebook. Namun demikian, hoaks tentang Covid-19 juga ditransmisikan melalui (grup) WhatsApps, Twitter, word of mouth (WOM), bahkan portal berita online.

\section{DAFTAR PUSTAKA}

Abner, Khaidir, Mohammad Ridho Abdillah, Rizky Bimantoro, Weiby Reinaldy. (2017). Penyalahgunaan Informasi Hoax Di Media Sosial. Laporan Penelitian. Universitas Bina Nusantara

Anwar, Fahmi. (2017). Perubahan dan Permasalahan Media Sosial. Jurnal Muara Ilmu Sosial, Humaniora, dan Seni. Volume 1 Nomor 1 April 2017: 137-144

Ardianto, Elvinaro, Lukiati Komala, dan Siti Karlinah. (2009). Komunikasi Massa: Suatu Pengantar. Bandung: Simbiosa Rekatama Media

Baran, Stanley J. dan Dennis K. Davis. (2010). Teori Komunikasi Massa Dasar, Pergolakan, dan Masa Depan: Edisi Lima. Jakarta: Salemba Humanika

Berelson and G.A. Steiner. (1964). Human Behavior: An Inventory of Scientific Finding. New York: Harcourt, Brace, and World Inc

Conner, C.V. (2011). Extortionware: The Official Guide to Finding and Removing. New York: Conner

Engel, James F., Roger D. Blackwell, dan Paul W. Miniard. (1995). Perilaku Konsumen: Edisi Keenam. Jakarta: Binarupa Aksara

Littlejohn, Stephen W. and Karen A. Foss. (2008). Theories of Human Communication ninth edition. California: Wadsworth Publishing Company

Littlejohn, Stephen W., Karen A. Foss, and John G. Oetzel. (2017). Theories of Human Communication: Eleventh Edition. Long Grove: Waveland Press Inc

Masyarakat Telematika Indonesia (Mastel). April, 2019. Wabah Hoaks Nasional. Jakarta

Moustakas, Clark. (1994). Phenomenological Research Methods. London: SAGE Publications

Mowen, Jhon C. dan Michael Minor. (2002). Perilaku Konsumen: Edisi Kelima. Jakarta: Erlangga

Nasrullah, Rulli. (2015). Media Sosial: Perspektif Komunikasi, Budaya, dan Sosioteknologi. Bandung: Simbiosa Rekatama Media

Prathama, Nikolaus Ageng. (2019). Aktivitas Pemrosesan Informasi SARA Dari Media Sosial. Tesis. Universitas Diponegoro Semarang

Rivers, William, L., Jay W. Jensen, dan Theodore Peterson. (2003). Media Massa dan Masyarakat Modern (Edisi Kedua). Jakarta: Prenada Media

Sarwono, Sarlito Wirawan. (1999). Psikologi Sosial Individu dan Teori-Teori Psikologi Sosial. Jakarta: Balai Pustaka

Sarwono, Sarlito Wirawan. (2013). Teori-Teori Psikologi Sosial. Jakarta: RajaGrafindo Persada

Setiadi, Nugroho J. (2003). Perilaku Konsumen: Perspektif Kontemporer Pada Motif, Tujuan, dan Keinginan Konsumen. Jakarta: Kencana

Shimp, Terence A. (2000). Periklanan Promosi: Aspek Tambahan Komunikasi Pemasaran Terpadu Jilid Satu: Edisi Kelima. Jakarta: Erlangga

Yusup, Pawit M. dan Priyo Subekti. (2010). Teori dan Praktik Penelusuran Informasi: Information Retrieval. Jakarta: Prenada Media

http://nasional.kompas.com/read/2017/04/18/13294431/pengguna.medsos.tinggi.berita.hoaks. semakin.mudah.menyebar, diakses pada 2 Juli 2020 
https://www.cnnindonesia.com/gaya-hidup/20200129123339-255-469800/dokter-bawangputih-belum-terbukti-obati-virus-corona, diakses pada 16 Juli 2020 https://lifestyle.okezone.com/read/2020/03/20/481/2186730/hoaks-virus-corona-covid-19yang-tersebar-di-whatsapp-group?page $=3$, diakses pada $17 \mathrm{Juli} 2020$

https://health.detik.com/berita-detikhealth/d-4880854/soal-hoax-bawang-putih-obati-viruscorona-kemenkes-singgung-impor-bawang, diakses pada 17 Juli 2020

https://inet.detik.com/cyberlife/d-4883463/masyarakat-lawan-hoax-virus-corona-sampai-jaditrending, diakses pada 17 Juli 2020

https://news.detik.com/berita-jawa-tengah/d-4882747/heboh-isu-virus-corona-di-semarangrsup-kariadi-tegaskan-hoax, diakses pada 17 Juli 2020

https://www.cnnindonesia.com/nasional/20200702091719-20-519881/daftar-53-zona-merahdan-99-zona-hijau-corona-di-indonesia, diakses pada 22 Juli 2020

https://news.detik.com/berita/d-4982087/menkominfo-ada-554-isu-hoax-soal-covid-19-89orang-jadi-tersangka, diakses pada 26 Juli 2020 